\title{
Review Paper: Nitrate Content in a Human Daily Intake
}

\author{
Snejana Dineva* \\ Department of Food Technology, Trakia University, Bulgaria
}

Submission: July 09, 2019; Published: September 20, 2019

"Corresponding author: Snejana Dineva, Department of Food Technology, Trakia University, Faculty of Technics and Technologies, Graf Ignatiev, Bulgaria

Abstract

There is no doubt that the quality of food closely related to the human health. That is why on that field are applying much efforts to educate young, inform people, produce and sell high quality food. The most usual contaminant of food is the high nitrate content in vegetables, water or cured meat. Nitrates and nitrites enter in the food chain through the polluted environment from intensive agriculture or from food industry where are used as food additives. Despite of all measures to produce and sell high quality food, human daily intake still can contain high number of nitrates or nitrites that can cause undesirable healthy problems.

Keywords: Food safety; Human health; Nitrates

Abbreviations: FM: Fresh Matter; EPA: Environmental Protection Agency

\section{Introduction}

The food quality is of the main concern for all governments. Guidelines and monitoring on the major food pollutants are accepted and applying in all over the world. One of the most common contaminants are nitrates and nitrites, which are often neglected as toxins and exert positive Umar \& Iqbal [1], Gunnar's [2] and negative Forman \& Shuker [3], Santamaria [4], WHO [5], EWG's [6,7] influence on the human health, in dependence of quantity that has been digested. The accepted daily intake of nitrates is calculated on the base of artificial presence in food as additives which preserve the food products Santamaria [4].

Nevertheless, the nitrate intakes derive not only from the cured meat and water, but mainly from vegetables, naturally. Vegetables can constitute more than $80 \%$ of dietary nitrates consumption Dich [8], Suzan [9], Hord [10], ATSDR [11], Brkić [12], Ranasinghe \& Marapana [13] from 300 to $940 \mathrm{mg} / \mathrm{g}$ Santamaria [4], when the nitrate contain of water is limited to $10 \mathrm{mg} / \mathrm{l}$ WHO [5]. Vegetables are considered as a main source of dietary nitrate in the human diet Knight et al. [14] compared to the amount received from processed meat Hord [10].

In meat products in order to preserve the red color and to prolong their shelf life are used potassium or sodium nitrates and nitrites as food additives Karl-Otto Honikel [15], WHO [5], EWG's [6,7], Smith-Welch [16]. Hence, in the most countries their use is usually limited by laws, and ingoing or the residual amounts are controlled. Most nitrate contamination of water and food products comes from animal waste or fertilizers Santamaria [4], EWG's [6,7].

\section{Healthy Effects of Nitrates}

The health effects of any hazardous substance depend on dose, duration, route of exposure, personal qualities and lifestyles, and on the end from the existing of other chemicals ATSDR [11]. Nitrate and nitrite ions are part of earth's nitrogen cycle, and a normal part of the nitrogen cycle in humans ATSDR [11]. Nitrates are considered as fewer toxic substances, but turn easy into nitrites, which form either nitric oxide or nitrosamines Karl-Otto Honikel [15] WHO [5]. The negative effects from digestion high number of nitrates can be developing of methemoglobinemia, disorders of thyroid glands, carcinogenicity and even malformations Hord [10], WHO [5]. The symptoms of exposure to high levels of nitrite are decreases in blood pressure, increased heart rate, headaches, methemoglobinemia, abdominal cramps, vomiting, and even death ATSDR [11].

\section{Methemoglobinemia}

The nitrates from the digestive tract are absorbed into the blood stream. The absorption starts from the stomach and up to upper small intestine they are fully assimilated WHO [5]. The studies demonstrated a link between nitrates and blood disorders in infants EWG's [6,7]. In infants, nitrites may cause 
methemoglobinemia, interacting with haemoglobin and reducing the ability of blood to transport oxygen Food safety [17]. The enzymes reducing the present of methaemoglobin back to haemoglobin are two-one NADH-dependent, and other NADPHdependent. Persons with a deficiency of NADH-dependent reductase easy developed symptomatic methemoglobinemia after exposure to nitrates and nitrites Kross \& Ayebo [18].

\section{Carcinogenicity}

According to Forman \& Shuker [3] the high number of nitrates in food are associated with stomach cancer. Nitrates are not carcinogenic in laboratory animals, but their reduction to nitrites, which can form nitrosamines in the body, increase the risk of cancer developing WHO [5], EWG's [6,7]. Nitrites can form carcinogenic nitrosamines under acidic stomach environment Karl-Otto Honikel [15], Smith-Welch [16] or they can be created directly in foods through high-heat cooking. In 2015, the World Health Organization's International Agency for Research on Cancer (IARC) identified processed meat as carcinogenic to humans BBC [19].

\section{Beneficial Effect}

In the oral cavity nitrates can turn into nitrites that exert antimicrobial activity and inhibit the growth of pathogenic microorganisms Umar \& Iqbal [1]. Also, nitrites can be turn into Nitric Oxide (NO) in the body, which is a signalling molecule that makes blood vessels dilate and reduces blood pressure Gunnars [2]. Thus, the high nitrate content naturally of beetroot juice has been attributed with reducing blood pressure and enhancing exercise performance Smith-Welch [16].

\section{Daily Intake Regulation}

Almost all countries regulated the nitrate content in food to protect human health Santamaria [4]. In most countries, N03ions in drinking-water do not exceed $10 \mathrm{mg} / \mathrm{l}$, and only if exceed $50 \mathrm{mg} / \mathrm{l}$ can be a major source of total nitrate intake WHO [5].

The US Environmental Protection Agency [20] set a Maximum Contaminant Level for nitrate of $44 \mathrm{mg} / \mathrm{L}$, equal to $10 \mathrm{mg}$ nitratenitrogen/L or $10 \mathrm{ppm}$, for drinking water. A new study indicating widespread nitrate pollution in U.S. drinking water -- at levels linked to increased cancer risk EWG's [6,7]. The legal limit for nitrates in drinking water in most countries is 10 parts per million Health Canada [21], WHO [5] EWG's [6,7], but recent research indicates that drinking water with more than $5 \mathrm{ppm}$ of nitrate increases the risk of kidney, colon, ovarian and bladder cancers EWG's $[6,7]$.

The Commission Regulation (EU) No 563/2002 sets limits for content of nitrates in vegetables in EU countries, but only for leafy green once (lettuce and spinach), which are considered as main source that constitute the daily ingestion. That regulation was amended two times in 2006 (EC Regulation No 1882/2006) and in 2011 with Commission Regulation (EU) No 1258/2011 [22]. In some countries are set limits to maximum levels of nitrate for trade of some vegetables (beetroot, cabbage, carrot, celery, endive, Lamb's lettuce, potato, radish and rocket) which form the main source of total dietary exposure of nitrate. For example, for potato in Germany the content should be less than $200 \mathrm{mg} / \mathrm{kg}$ Fresh Matter (FM), while in Poland there is a maximum limit of $183 \mathrm{mg} / \mathrm{kg}$ FM Santamaria [4].

Nonetheless, of restrictions and regulations accepted to control and minimize nitrate intake from human food, there are still vegetables on the EU market with exceeded levels. The assessment of human population nitrate exposure in Italy confirm that the acceptable daily intake was higher than the settled limits $3.7 \mathrm{mg} / \mathrm{kg}$ bw per day and that the ingestion of nitrates from vegetables mainly generate the highest exposure to people of all ages Roila [23].

According to Smith-Welch [16], the widely varied diet with at least five servings a day of fruit and vegetables, and less nibbling on processed meats may prevent from the intake of a potentially carcinogenic nitrates and nitrites [24-26].

\section{Conclusion}

All types pollution of food are undesirable and all governments' sets limits and monitoring programmes to control in the margins the possible toxic substances. There is no food product without contaminants but keeping a less amount of them e.g. the acceptable daily intake can be guaranty for good food quality.

\section{References}

1. Umar ASH, Iqbal M (2007) Nitrate Accumulation in Plants, Factors Affecting the Process, and human health implications. A review. Agron Sustain Dev 27(1): 45-57.

2. Gunnars k (2017) Are Nitrates and Nitrites in Foods Harmful?

3. Forman D, Shuker (1997) Helicobacter Pylori and Gastric Cancer. A case Study in Molecular Epidemiology. Mutation Research/Fundamental and Molecular Mechanisms of Mutagenesis 379: 159.

4. Santamaria P (2006) Review Nitrate in Vegetables: Toxicity, Content, Intake and EC Regulation. J Sci Food Agric 86 (1): 10-17.

5. WHO (2011) Nitrate and Nitrite in Drinking-Water?

6. Ewg's (2018) Ewg Study Indicates Widespread Nitrate Pollution.

7. EWG's Children's Health Initiative (2015) How to Avoid Added Nitrates and Nitrites in Your Food. UK.

8. Dich J, Jivinen R, Knekt P, Pentill Pl (1996) Dietary Intakes of Nitrate, Nitrite and Ndma in the Finish Mobile Clinic Health Examination Survey. Food Addit Contam 13(5): 541-552.

9. Sušin J, Kmecl V, Gregorčič A (2006) A Survey of Nitrate and Nitrite Content of Fruit and Vegetables Grown In Slovenia During 1996-2002. Food Addit Contam 23(4): 385-390.

10. Hord Ng, Tang Y, Bryan Ns (2009) Food sources of nitrates and nitrites: the physiologic context for potential health benefits. Am J Clin Nutr 90(1): 1-10

11. ATSDR (2015) Nitrate and nitrite. Toxic substances portal. Georgia.

12. Brkić D, Bošnir J, Bevardi M, Gross Bošković A, Miloš S, et al. (2017) Nitrate in Leafy Green Vegetables and Estimated Intake. Brkic et al., Afr J Tradit Complement Altern Med 14(3): 31-41. 
13. Ranasinghe Rasn, Rauj Marapana (2018) Nitrate and Nitrite content of Vegetables: a Review. Journal of Pharmacognosy and Phytochemistry $7(4): 322-328$.

14. Knight TM, Forman D, Al-Dabbagh SA, Doll R (1987). Estimation of Dietary Intake of Nitrate and Nitrite in Great Britain. Food Chem Toxicol 25(4): 277-85.

15. Honikel KO (2008) The use and Control of Nitrate and Nitrite for the Processing of Meat Products. Meat Sci 78(1-2): 68-76.

16. Smith welch A (2019) The Truth About the Nitrates in Your Food.

17. Food safety (2019) Nitrates \& nitrites (preservatives).

18. Kross BC, Ayebo A (1995) Environmental medicine: integrating a missing element into medical education. Nitrate/Nitrite Toxicity.

19. BBC (2018) Calls to Rid Bacon and Ham of Processing Nitrites.

20. Us Environmental Protection Agency (2009) Technical Factsheet on: Nitrate/Nitrite. USA.
21. Health Canada (2013) Guidelines for Canadian Drinking Water Quality: Guideline Technical Document - Nitrate and Nitrite. Water and Air Quality Bureau, Healthy Environments and Consumer Safety Branch, Health Canada, Ottawa, Ontario.

22. EC (2011) Commission Regulation Amending Regulation (ec) no $1881 / 2006$ as Regards Maximum Levels for Nitrates in Foodstuffs.

23. Roila R, Branciari R, Staccini B, Ranucci D, Miraglia D, et al. (2018) Contribution of Vegetables and Cured Meat to Dietary Nitrate and Nitrite Intake in Italian Population: Safe Level for Cured Meat and Controversial Role of Vegetables. Ital J Food Saf 7(3): 7692.

24. Angelova M (2017) How to Deal with Nitrate in Food.

25. Kmecl V, Tea Knap, Dragan Žnidarčič (2017) Evaluation of the Nitrate and Nitrite Content of vegetables Commonly Grown in Slovenia.

26. Stachniuk A, Szmagara AG, Anna stefaniak EL (2018) Spectrophotometric assessment of the differences between total nitrate/nitrite contents in peel and flesh of cucumbers. Food analytical methods 11(10): 2969-2977.

\section{Your next submission with Juniper Publishers will reach you the below assets}

- Quality Editorial service

- Swift Peer Review

- Reprints availability

- E-prints Service

- Manuscript Podcast for convenient understanding

- Global attainment for your research

- Manuscript accessibility in different formats

( Pdf, E-pub, Full Text, Audio)

- Unceasing customer service

Track the below URL for one-step submission https://juniperpublishers.com/online-submission.php 